\title{
ISSUES IN TEACHING SPEAKING IN BILINGUAL CLASS
}

\author{
Mildan Arsdan Fidinillah \\ Program of English Education, Faculty of Language and Art, University of Indraprasta PGRI \\ Jalan Nangka No. 58C Tanjung Barat, Jagakarsa, South Jakarta 12530 \\ mildan_fidinillah@yahoo.com
}

\begin{abstract}
Students who study in bilingual class are expected to have the ability of speaking English as well as Indonesian. This research looks at the learning steps in teaching speaking English in bilingual class that claimed their students are able to speak fluently in English within one year. The research data was taken from two bilingual classes at Madrasah Ibtidaiyah Negeri (MIN) Ciputat, South Tangerang City, Banten. The sample of this study was 20 bilingual class students from class 6 . The instruments of the research are questionnaire and class observation. Questionnaire is given to the teachers related to their methods in teaching speaking English whereas class observation is conducted to see the ability of students in speaking English. This research is limited only to the analysis of teaching steps of English speaking in the bilingual class. The results of this study indicate that by practicing the cluster method carried out by the teacher, the students' English speaking skill is improved significantly in a short time.
\end{abstract}

Key Words: bilingual, monolingual, literacy instruction

\begin{abstract}
ABSTRAK
Siswa yang belajar di kelas bilingual diharapkan memiliki kemampuan berbicara bahasa Inggris sebaik bahasa Indonesia. Penelitian ini bertujuan untuk mencari tahu langkahlangkah pembelajaran yang terkait dengan kemampuan berbicara bahasa Inggris di kelas bilingual yang mengklaim siswanya dapat dengan mahir berbicara bahasa Inggris dalam waktu satu tahun. Data-data penelitian diambil dari dua kelas bilingual di Madrasah Ibtidaiyah Negeri (MIN) Ciputat Kota Tangerang Selatan Banten. Sampel penelitian ini adalah 20 siswa kelas bilingual yang berasal dari kelas 6. Instrumen dari penelitian ini adalah angket dan observasi kelas. Angket diberikan kepada guru untuk melihat metode mengajar yang terkait dengan kemampuan berbicara sementara observasi kelas dilakukan untuk melihat sejauh mana kemampuan berbicara bahasa Inggris siswa. Penelitian ini dibatasi hanya pada analisis mengenai langkah-langkah pengajaran berbicara bahasa Inggris di kelas bilingual. Hasil penelitian ini menunjukan bahwa dengan mempraktekan metode kluster yang dilakukan oleh guru, kemampuan berbicara bahasa Inggris siswa dapat meningkat secara signifikan dalam waktu yang relatif singkat.
\end{abstract}

Kata Kunci: dwi bahasa, bahasa tunggal, instruksi lisan 


\section{INTRODUCTION}

When we hear the term "bilingual", we will think something related to the language. Some people defined bilingual as a person who speak two languages natively, others say bilingual means that someone is fluent in two languages. There are also many people who say that bilingual means simply to be able to communicate in two languages. It really isn't clear cut, because the word "fluent" can also mean different things to different people. And, it varies on who you speak to, or which research you read, as to how fluent someone needs to be, to be called bilingual. Many people who are bilingual have acquired two languages from their early childhood. They may have had parents who spoke two different languages with them, or they may have lived in a community where the language spoken outside, was different to the one spoken at home.

Bilingual primarily describes someone with the possession of two languages. Others may have been brought up with one language, and acquired another language later in life. They may have studied the language at school, had a bilingual education, travelled, or learned for other reasons. When you look at what it means to be bilingual, different people have different ideas on how fluent someone needs to be in the two languages they speak, to actually be considered bilingual. "Speaking two languages fluently" is one definition. But if we talk about monolinguals who speak only one language, and we consider everyone "fluent" in that language, there are many differences in the levels of "fluency." Sometimes the amount of education a person has received will influence the amount of vocabulary they have. It means that someone less educated is less fluent in their native language. Luoma
(2009:1) argues that "Speaking skills are an important part of the curriculum in language teaching, and this makes them an important object of assessment as well".

Bailey and Nunan (2005) say that speaking is an interactive process of constructing meaning involving a production and a process of information.Related to many people who call their children bilinguals when they are raised to speak two languages, even if they are young and do not yet speak those languages fluently. Some children learn quicker than others, some take a little more time to master both languages. It is a though that if a child can speak their languages to the level of their peers, that those languages would be considered native, and therefore those children can be called bilinguals. However, there are some who would disagree if one language isn't as fluent as the other. There is also the question of reading and writing. For a person who is able to speak, read and write in both languages, some people will call him as bilingual. Many people consider themselves bilingual if they have been brought up with two languages, even if they are not equally fluent in both, or if they can only read and write in one language. Professionals in the field say that not all bilinguals will have the same proficiency in both languages they speak anyway.

In many cases, one of the languages is stronger. Bilinguals know their languages to the level that they need them. Some bilinguals are dominant in one language, others do not know how to read and to write one of their languages, others have only passive knowledge of a language and, finally, a small minority, have equal and perfect fluency in their languages. What is important to keep in mind is that bilinguals are very diverse, as are monolinguals. How and why a 
person acquired their languages can influence their own, and others' perception of the word bilingual.

Harmer (2000:34) added:

"Both students and teachers need to know how to talk about language at various points during learning and teaching. This is not only so that teachers can explain and students come to understand, but also so that teachers know what's going wrong where and how to correct it."

While one person who was brought up in a bilingual household may not consider herself/himself as a bilingual, she/he will not be able to speak both languages to the same level. Meanwhile, others may believe that they are bilinguals as soon as they are able to express themselves comfortably in both languages. People may not consider themselves bilinguals simply because they learned a language later in life, rather than from birth, whereas another may not use the language anymore. There are definitions in a dictionary, and from professionals in the field, however sometimes it comes down to how people feel being able to express themselves in both of their languages. There are so many ways to be called bilingual.

There is a condition when half of a class speaks one language, but the other half is raised speaking another. Philips (2007:26) stated that "Speaking is an interactive process constructing meaning that involves producing and receiving and processing". As a teacher, it's physically impossible to speak more than one language at a time, and no matter how much you slow down, repeat instructions or demonstrate the task at hand, often you're met with blank stares - or worse, students who checked out the second you started using their second language. Accordingly, Jordan (2009) explained that speaking is the process of expressing feeling and thought spoken in words. This means that speaking is the process of delivering meaning by using verbal utterances at any situations in various contexts.

Timing will be surely as a problem in the teaching process. By using interactive notes including key learning points and gaps will create teaching-learning process effectively. Teachers in dual language classrooms face an incredible challenge: they need to teach a linguistically diverse class of students to read and to write in both languages, while also teaching increasingly difficult on the academic content in two languages. While research points to numerous benefits of bilingual schooling, our teachers are the ones who need to - almost magically - turn a class full of kids into bilingual learners. This research article aims to provide educators with some fundamental strategies to promote linguistic crosspollination among students in dual language classrooms.

Firstly, use group work strategically. One advantage of duallanguage classrooms is the opportunity for students to work with classmates who are not from the same community, language background or culture. Next time creating groups, think about how to structure them. On one hand, heterogeneous groups allow students to practice communicating and collaborating across languages and cultures, while on the other, homogenous groups allow students to tailor specific learning objectives to learners with differentiated needs. Secondly, designing group tasks will create both structured and unstructured opportunities for kids to use their languages. In the classroom, this might be a task where students need to use formal language to plan a group project according to a graphic organizer (structured), or to interview classmates 
and collect data based on these projects (unstructured).

Adopting a content-based language instruction approach, to keep up with the academic rigors for your language learners, content-based language instruction is an effective teaching approach that incorporates both language and content area objectives into each lesson. One way to think about it is to have a SWBAT (students will be able to) for content area objectives, and another SWBAT for the language objectives. For example, when teaching a unit on the lifecycle of butterflies, a content objective might be for students to explain the lifecycle in a poster presentation, while the language objective would be to use the language of sequencing (i.e. first, then, next, etc.) to express the lifecycle. Make sure students know what the content and language goals are for each lesson, so they can self-regulate their learning and reflect on how well they achieved each objective.

Maintain a positive relationship with all students, though it may not seem like a strategy, research shows that students from any linguistic or ethnic background who have positive social interactions with their teachers have better academic performance. As a teacher, she/he should reflect on how she/he perceives student's behavior and achievement in the class, and recognizes the biases brought to the classroom as she/he interacts with students from backgrounds that are different from your own. Challenge labels and dispel stereotypes that are pinned to children who shuffle through the school system (i.e. negative connotations associated with "special education" and "ELLs"); show kids that you are devoted to their education.

Set clear expectations about when to use each language, in dual language classes, it is very natural for students who want to use their native language to express themselves. This, however, often results in children who only speak to others with the same language background. To encourage students to persevere in their second language, try setting expectations about which language students should be using during different parts of the day, lesson, or task. Not only they will learn about how to problem solve in moments of linguistic difficulty (i.e. asking their peers for help), but they will also be exposed to, and better able to emulate their peers who are native language speakers of their second language.

For the teacher, studies also show that monolingual lesson delivery is more effective than language mixing during lessons. Monolingual lesson delivery means that for a certain period of time, instruction is only given in one particular language, without translation from teacher assistants or other aids. This engages students in prolonged language exposure of academic content in their second language, and helps them develop listening strategies in their second language.

As conclusion, allowing students to trans language, when thinking about language policies, remember that children who come from bilingual homes often 'trans language', which is the act of strategically using words from two linguistic repertoires to communicate effectively. This could be saying one sentence in English then another, or even mixing the two languages within one sentence. Welcoming this natural linguistic process into the classroom allows children to engage in the rigors of difficult academic content, and to express themselves in deep classroom discussions as they draw from their two languages as a resource. In time, as students gain a stronger command for 
each language, they will also gain confidence to communicate in each language individually. Most importantly, because they were able to trans language, they will not have missed out on crucial big ideas and class debates that were discussed in their developing second language.

\section{METHOD}

This research is a qualitative research because the researcher takes place in the real situation about social phenomena. In order to obtain the data related to the research, the researcher distributes the questionnaires to the sample teachers to know their teaching steps they use in daily teaching and learning. This is the primer data of the research, while for secondary data, the researcher distributes the speaking test to the sample students to examine their ability is speaking English. The population of this research is all students and teachers at bilingual classrooms in Madrasah Ibtidaiyah Negeri Ciputat Kota Tangerang Selatan The population of this research is all students and teachers at bilingual classrooms in Madrasah Ibtidaiyah Negeri Ciputat Kota Tangerang Selatan Banten and the sample was the sixth grade of bilingual class consist of 20 students and also 6 bilingual teachers. The instrument of this research will be the two. The first is questionnaire to collect the data on teachers' teaching steps. The second is speaking test to collect the data about students' speaking English ability.

The researcher collects, identifies and analyzes all the teaching steps done by the teachers from grade one until six. There will be three times checking for data validation for this research to eliminate the improper data. After that, the researcher gets the data analysis result and the data will be described by words or sentences related to those teaching steps and students ability of speaking. The researcher uses some steps to analyze the data such as collecting, analyzing and categorizing the data and the last step, the researcher classifies the teaching steps of English teachers in the bilingual class to some clusters to see which first, second, third and next others steps of teaching speaking to the students that is assumed can improve their speaking ability in very short time.

\section{RESULTS AND DISCUSSION}

In this research, the researcher collects data from the teachers who teach in Bilingual class. The teachers in that class teach lesson variation related with English acquisition especially speaking. The ability to speak English fluency becomes the most important goal in bilingual class teaching and learning process. The teachers as respondent of this research teach many skills such as listening, reading and writing beside some others components like vocabulary, grammar and pronunciation to support finally the speaking teaching and learning process.

The teaching steps done by teachers as respondents of this research are the steps of teaching done by teachers in some time allocations during one year to reach the goal of teaching and learning. In one year, the teachers who teach in the bilingual class have to be able to change class situation from Indonesian language speaker to be English language speaker. The teaching steps are needed to group the lessons related each other beside to focus the students activities related with the fluency of English speaking as the main goal of teaching and learning process. The data will be this teaching steps based on the time allocation provided such as the first four months, the second four months and the third four months. 
The first four months is the step for collecting vocabularies. In this step, teachers list their students' vocabularies periodically. A method of testing students' general knowledge of vocabulary is to ask them the meaning of several words that appear in textbooks at their grade level. This will give you an estimate of how well the students' vocabulary knowledge matches their grade level. However, it will not allow you to compare the vocabulary achievement of your students with those in the country as a whole. If you are a teacher in a school with a large group of students from a low socio-economic level, this method of testing vocabulary knowledge may give you "tunnel vision," because students with only a normal vocabulary may appear very good in comparison to other students in the class.

When there is a need to determine if a student knows the meaning of a specific word rather than him/her general vocabulary level, just ask him/her to tell you what the word means. Unfortunately, that is difficult to do with a large group of students. Two methods that can be used to determine if a group of students know the meanings of a specific set of words are a self-check assessment or a multiple-choice assessment. In the self-check assessment, the student simply looks at a list of words and places a check mark by the words of which he/she knows the meaning. In the multiple-choice assessment, a teacher provides the target word and a choice of several possible meanings or synonyms.

The second four months is the step for revising and editing sentence grammar and structure. Grammar is the sound, structure, and meaning system of language. All languages have grammar, and each language has its own grammar. People who speak the same language are able to communicate because they intuitively know the grammar system of that language - that is, the rules of making meaning. Students who are native speakers of English already know English grammar. They recognize the sounds of English words, the meanings of those words, and the different ways of putting words together to make meaningful sentences. However, while students may be effective speakers of English, they need guidance to become effective writers. They need to learn how to transfer their knowledge of grammatical concepts from oral language to written language.

Effective grammar instruction begins with what students already know about grammar, and it helps them use this knowledge as they write. By connecting their knowledge of oral language to written language, teachers can demystify abstract grammatical terminology so that students can writeand read-with greater competence and confidence. Research strongly suggests that the most beneficial way of helping students improve their command of grammar in writing is to use students' writing as the basis for discussing grammatical concepts.

Researchers agree that it is more effective to teach punctuation, sentence variety, and usage in the context of writing than to approach the topic by teaching isolated skills. As students revise and edit their writing, teachers can provide grammar instruction that guides students in their attempts to identify and to correct problems in sentence structure and usage. For example, a teacher who sees that many students are writing sentences containing misplaced modifiers can present a mini lesson on this concept, using examples from student's writing. The teacher can have students edit their own and one another's drafts for this 
problem. Integrating grammar instruction into the revising and editing process helps students make immediate applications, thus allowing them to see the relevance of grammar to their own writing.

The third four months is practicing speaking English. In this activity, students are conditioned to always speak English every time and everywhere in the school environment. The teacher does not provide opportunities for students to speak Indonesian except during their Indonesian lesson hours in class. There are punishments given by the teacher when getting students to speak other languages than English. Students are also given methods every day that can accelerate their ability to speak English such as debate, speech, promptu speaking, telling story, presentation, discussion, question and answer, dialogue, and so on. When students are given certain methods to improve their speaking skills and it is combined with a setting to always speak English, the result is very effective. Within a short period, in one year, students in the bilingual class were fluently enough to speak English.

\section{CONCLUSION}

With appropriate, wellstructured and good-systematic steps of learning, the acceleration of students in English speaking skills mastery can be realized. Through this research, the steps of learning English are practiced by teachers and students in the bilingual class above like the step for collecting vocabularies, the step for revising and editing sentence grammar and structure and the step for practicing speaking English scientifically proven to make students speak English in approximately one year. The first suggestion is intended for the teachers who are competent to create good atmosphere to facilitate teaching and learning process. The second is for the English students who are interested in improving their speaking skill, thus they can be aware to their speaking ability. The last is for further researchers who will conduct a next research related to this research study.

\section{REFERENCES}

Bailey, K. M., \& Nunan, D. (2005). Practical English Language Teaching Speaking. New York: McGraw-Hill.

Harmer, J. (2000). How to Teach Writing. Kuala Lumpur: Longman.

Jordan, R. R. (2009). Teaching Speaking for Beginner. Collins: London and Glasgow.

Luoma, S. (2009). Assesing Speaking. New York: Cambridge University Press.

Philips, J. (2007). Speaking Technique. Boston: Little, Brown and Co. 